\title{
Millennial changes in North Atlantic oxygen concentrations
}

\author{
B. A. A. Hoogakker ${ }^{1}$, D. J. R. Thornalley ${ }^{2}$, and S. Barker ${ }^{3}$ \\ ${ }^{1}$ Department of Earth Sciences, University of Oxford, Oxford, OX1 3AN, UK \\ ${ }^{2}$ Department of Geography, University College London, London, WC1E 6BT, UK \\ ${ }^{3}$ School of Earth and Ocean Sciences, Cardiff University, Cardiff, CF10 3AT, UK
}

Correspondence to: B. A. A. Hoogakker (babetteh@earth.ox.ac.uk)

Received: 30 June 2015 - Published in Biogeosciences Discuss.: 13 August 2015

Revised: 30 November 2015 - Accepted: 2 December 2015 - Published: 15 January 2016

\begin{abstract}
Glacial-interglacial changes in bottom water oxygen concentrations $\left[\mathrm{O}_{2}\right]$ in the deep northeast Atlantic have been linked to decreased ventilation relating to changes in ocean circulation and the biological pump (Hoogakker et al., 2015). In this paper we discuss seawater $\left[\mathrm{O}_{2}\right]$ changes in relation to millennial climate oscillations in the North Atlantic over the last glacial cycle, using bottom water $\left[\mathrm{O}_{2}\right]$ reconstructions from 2 cores: (1) MD95-2042 from the deep northeast Atlantic (Hoogakker et al., 2015) and (2) ODP (Ocean Drilling Program) Site 1055 from the intermediate northwest Atlantic. The deep northeast Atlantic core MD95-2042 shows decreased bottom water $\left[\mathrm{O}_{2}\right]$ during millennial-scale cool events, with lowest bottom water $\left[\mathrm{O}_{2}\right]$ of 170,144 , and $166 \pm 17 \mu \mathrm{mol} \mathrm{kg}^{-1}$ during Heinrich ice rafting events $\mathrm{H} 6$, $\mathrm{H} 4$, and H1. Importantly, at intermediate depth core ODP Site 1055 , bottom water $\left[\mathrm{O}_{2}\right]$ was lower during parts of Marine Isotope Stage 4 and millennial cool events, with the lowest values of 179 and $194 \mu \mathrm{mol} \mathrm{kg}{ }^{-1}$ recorded during millennial cool event C21 and a cool event following DansgaardOeschger event 19. Our reconstructions agree with previous model simulations suggesting that glacial cold events may be associated with lower seawater $\left[\mathrm{O}_{2}\right]$ across the North Atlantic below $\sim 1 \mathrm{~km}$ (Schmittner et al., 2007), although in our reconstructions the changes are less dramatic. The decreases in bottom water $\left[\mathrm{O}_{2}\right]$ during North Atlantic Heinrich events and earlier cold events at the two sites can be linked to water mass changes in relation to ocean circulation changes and possibly productivity changes. At the intermediate depth site a possible strong North Atlantic Intermediate Water cell would preclude water mass changes as a cause for decreased bottom water $\left[\mathrm{O}_{2}\right]$. Instead, we propose that the lower bottom $\left[\mathrm{O}_{2}\right]$ there can be linked to productivity changes through increased export of organic material from the surface ocean
\end{abstract}

and its subsequent remineralization in the water column and the sediment.

\section{Introduction}

Oxygen is vital to all aerobic life. Oxygen solubility in seawater is highly temperature dependent, with salinity playing a secondary role. The $\left[\mathrm{O}_{2}\right]$ of a (deep or intermediate) water mass at a particular location is determined by its initial concentration at the region of sinking, the amount of respiration it has undergone, and mixing with other water masses. Both oxygen supply and consumption are ultimately driven by ocean circulation and biology (Schmittner et al., 2007). Climate models predict that oxygen concentrations in the ocean will decrease substantially in response to anthropogenic climate change. Recent expansion of tropical subsurface oxygen minimum zones have been attributed to this effect (Stramma et al., 2010). The warming effect on $\left[\mathrm{O}_{2}\right]$ loss is twofold: (1) less oxygen can be dissolved at higher sea water temperatures; (2) warmer surface waters may increase upper ocean stratification, and it is thought that the resulting decreased ventilation effect exceeds that associated with reduced oxygen utilization (Sarmiento et al., 1998; Matear et al., 2000; Plattner et al., 2001; Bopp et al., 2002; Keeling and Garcia, 2002; Keeling et al., 2010). A global ocean decline in $\left[\mathrm{O}_{2}\right]$ between 1 and $7 \%$ has been predicted over the next century (Keeling et al., 2010); over longer timescales (e.g. 100s-1000s of years) a slowdown in ocean overturning has been predicted to potentially cause an overall decrease in $\left[\mathrm{O}_{2}\right]$ of $30 \%$, with declines in the deep ocean projected to between 20 and $40 \%$ by the year 2800 (Matear and Hirst, 2003; Schmittner et al., 2008; Shaffer et al., 2009). How- 

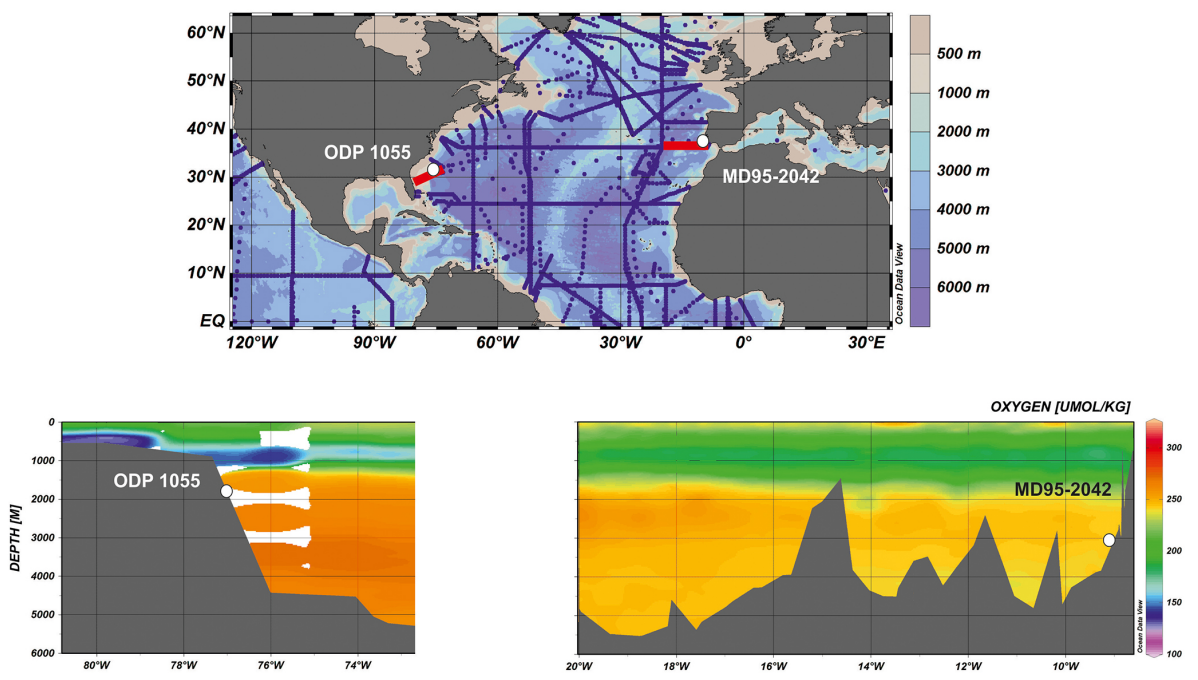

Figure 1. Locations of the two cores (ODP 1055, MD95-2042) used in this study projected on a global bathymetric map (top panel). The red sections show the locations of the two sea water $\left[\mathrm{O}_{2}\right]$ profiles shown in the bottom panel. $\left[\mathrm{O}_{2}\right]$ profiles were made using GLODAP version 1.1 bottle data (Key et al., 2004). Cross sections and map were created using Ocean Data View (Schlitzer, R., Ocean Data View, http://odv.awi.de, 2009).

ever, there are large uncertainties associated with coarseresolution ocean models in simulating today's and also future $\left[\mathrm{O}_{2}\right]$ distributions (e.g. Jin and Gruber, 2003).

The future reduction in ocean overturning is mainly attributed to changes in surface heat flux and to a lesser extent to surface freshening (Gregory et al., 2005). Beyond the last couple of decades there are no direct observations of deep water $\left[\mathrm{O}_{2}\right]$. However, palaeoceanographic proxies of overturning circulation and ocean ventilation as well as redox proxies provide constraints of changes in deep water $\left[\mathrm{O}_{2}\right]$ in relation to specific climatic events.

The effects of large-scale changes in Atlantic circulation on deep water $\left[\mathrm{O}_{2}\right]$ are probably best studied during the last glacial period, which was punctuated by a series of millennial-scale cold events associated with the advance of large-scale iceberg armadas (Bond and Lotti, 1995) and thought to involve systematic changes in the northward heat transport associated with the Atlantic Meridional Ocean Circulation (AMOC) (Stocker and Johnson, 2003; Barker et al., 2011). Nutrient proxies (benthic foraminiferal carbon isotopes $\left(\delta^{13} \mathrm{C}\right)$ and $\mathrm{Cd} / \mathrm{Ca}$ ) and ocean circulation proxies $\left(\mathrm{Pa} / \mathrm{Th},{ }^{14} \mathrm{C}\right.$ ventilation times) (McManus et al., 2004; Hoogakker et al., 2007; Skinner et al., 2010), provide evidence for increased deep water nutrients and reduced ventilation and overturning circulation in the North Atlantic during cold stadial events (Schmittner and Lund, 2015) and point to decreased deep water $\left[\mathrm{O}_{2}\right]$. Redox sensitive proxies are particularly useful to assess qualitative changes in bottom water $\left[\mathrm{O}_{2}\right]$ (Nameroff et al., 2002; Pailler et al., 2002; Jaccard et al., 2009). Recently, Hoogakker et al. (2015) refined a novel proxy originally proposed by McCorkle and Emerson (1988), where bottom water $\left[\mathrm{O}_{2}\right]$ can be reconstructed from the carbon isotope gradient between bottom water and pore water at the anoxic boundary. Hoogakker et al. (2015) suggest that bottom water $\left[\mathrm{O}_{2}\right]$ in the deep northeast Atlantic $(3.1 \mathrm{~km})$ were 45 and $65 \mu \mathrm{mol} \mathrm{kg}{ }^{-1}$ lower during the last and penultimate glacials relative to today. Their reconstructions also showed significantly reduced bottom water $\left[\mathrm{O}_{2}\right]$ during extreme cold events associated with large-scale ice rafting and the deposition of ice-rafted debris in the North Atlantic (Hoogakker et al., 2015). Here we discuss the underlying causes for millennial-scale reductions in bottom water $\left[\mathrm{O}_{2}\right]$ in the deep $(3.1 \mathrm{~km})$ North Atlantic. In addition we present new, millennial-scale-resolved, bottom water $\left[\mathrm{O}_{2}\right]$ reconstructions in the North Atlantic from the intermediate depth $(1.8 \mathrm{~km})$ core ODP (Ocean Drilling Program) Site 1055 , located on the Carolina Slope off North America.

\section{Locations}

Core MD95-2042 was taken during the 1995 IMAGES cruise from the Iberian Margin $\left(37^{\circ} 48^{\prime} \mathrm{N}, 10^{\circ} 10^{\prime} \mathrm{W}, 3146 \mathrm{~m}\right.$ water depth; Fig. 1) off southern Portugal in the northeast Atlantic (Bassinot et al., 1996). ODP Site $1055\left(32^{\circ} 47 \mathrm{~N}, 76^{\circ} 17 \mathrm{~W}\right.$, $1798 \mathrm{~m}$ water depth, Fig. 1) is located in the subtropical northwest Atlantic, slightly upslope of the Blake Outer Ridge on the lower Carolina Slope. Core MD95-2042 is currently bathed in well-ventilated $\left(\left[\mathrm{O}_{2}\right]\right.$ of $\left.\sim 245 \mu \mathrm{mol} \mathrm{kg}{ }^{-1}\right)$ northward re-circulating Northeast Atlantic Deep Water (NADW), whereas during glacial times bottom waters with a Southern Ocean origin (Southern Source Deep Water, SSDW) became more important (Shackleton et al., 2000; Skinner and Shackleton, 2004). ODP Site 1055 is currently located within the core of well-oxygenated Labrador Sea Water, with the main 
flow axis of lower North Atlantic Deep Water being found at greater depths, $\sim 2500-4000 \mathrm{~m}$ (Stahr and Stanford, 1999). Bottom waters near ODP Site 1055 have slightly higher $\left[\mathrm{O}_{2}\right]$ compared with MD95-2042, with values between 250 and $254 \mu \mathrm{mol} \mathrm{kg}^{-1}$ (Fig. 1). During glacial times and cold stadial periods, ODP Site 1055 was largely influenced by Glacial North Atlantic Intermediate Water (GNAIW) (e.g. Evans and Hall, 2008; Thornalley et al., 2013).

\section{Methods}

\subsection{Age models}

The age models of both cores were constructed by correlating planktonic (surface dwelling) foraminiferal oxygen isotope $\left(\delta^{18} \mathrm{O}_{p}\right)$ records with North Greenland Ice Core Project (NGRIP) $\delta^{18} \mathrm{O}_{\text {ice }}$ (NGRIP Members, 2004). Both marine and ice core records show a series of oscillating cycles of rapid warmings followed by gradual cooling (e.g. DansgaardOeschger cycles), culminating in extreme cold events that are associated with the deposition of massive layers of ice-rafted debris (IRD) in the North Atlantic (e.g. Heinrich events) (Heinrich, 1988; Johnsen et al., 1992; NGRIP project Members, 2004; Shackleton et al., 2000, 2004). Typically, six Heinrich layers, H1-H6, have been described for Marine Isotope Stage (MIS) 3 (29-60 ka BP, before present) and a further five, H7-H11, over MIS 4 and 5 (between 60 and $130 \mathrm{ka}$ BP). However, outside the Labrador Sea such IRD layers contain conspicuously less detrital carbonate (a defining criterion for a Heinrich layers) and are labelled C19-C25 (Chapman and Shackleton, 2002). For the interval 0-60 ka the GICC05 (Greenland Ice Core Chronology 2005) age model was applied, whose ages are very similar to that of the SFCF 2004 age model as was used previously in Hoogakker et al. (2015). Thornalley et al. (2013) apply a revised chronology prior to $60 \mathrm{ka}$, based on the speleothem-tuned age model of Barker et al. (2011), and to aid comparison between the two sites the same chronology was applied to MD95-2042 between 60 and $123 \mathrm{ka}$. Based on these age models, results of core MD95-2042 cover the last $150 \mathrm{kyr}$, whilst those of core ODP Site 1055 cover the interval 85-59 ka BP (Fig. 2).

\subsection{Sea water $\left[\mathrm{O}_{2}\right]$}

The biogeochemical cycles of oxygen and carbon are stoichiometrically linked through photosynthesis and respiration. Photosynthesis uses carbon dioxide $\left(\mathrm{CO}_{2}\right)$, water, sunlight and nutrients to make organic material and oxygen. The breakdown of organic material, in well-oxygenated environments, uses oxygen and produces $\mathrm{CO}_{2}$. During photosynthesis, organisms preferentially take up ${ }^{12} \mathrm{C}$, which is isotopically light compared with ${ }^{13} \mathrm{C}$, causing an overall enrichment of the carbon isotopic composition $\left(\delta^{13} \mathrm{C}\right)$ of DIC (dissolved inorganic carbon) in surface waters (Kroopnick, 1985; Gruber et al., 1999). When organic material is broken down,

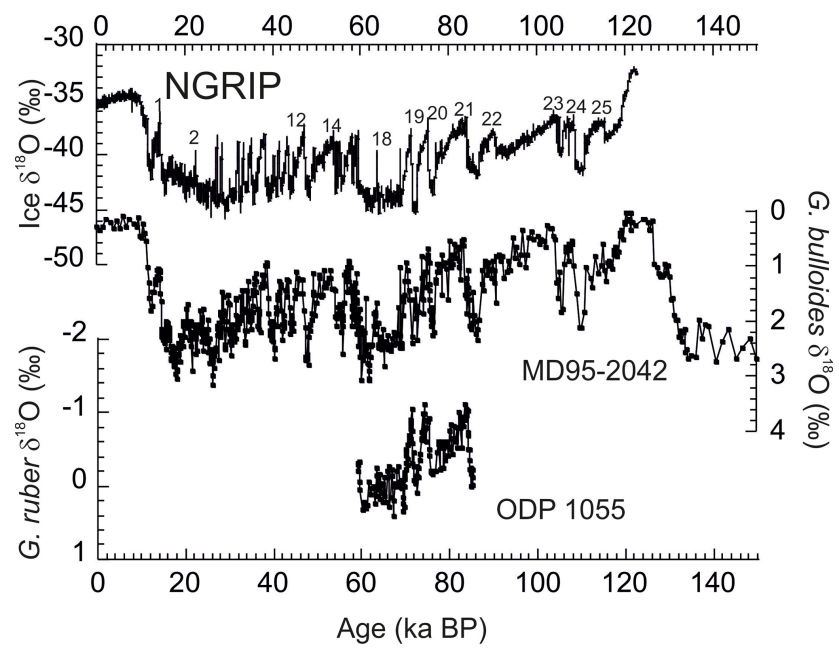

Figure 2. Age models of MD95-2042 and ODP 1055 established by tying planktonic foraminifera oxygen isotope changes of Globigerina bulloides (MD95-2042; Shackleton et al., 2000) and Globigerinoides ruber (ODP Site 1055) to those of NGRIP. Several Dansgaard-Oeschger interstadial events are numbered in the NGRIP records.

the release of light ${ }^{12} \mathrm{C}$ causes a depletion in seawater $\delta^{13} \mathrm{C}$ DIC. Globally there is a strong linear relationship between deep water $\left[\mathrm{O}_{2}\right]$ and $\delta^{13} \mathrm{C}$, where a $50 \mu \mathrm{mol} \mathrm{kg}{ }^{-1}$ decrease in $\left[\mathrm{O}_{2}\right]$ corresponds to a $0.34 \%$ o decrease in seawater $\delta^{13} \mathrm{C} \mathrm{DIC}$ (Fig. 3), with $R^{2}$ between 0.78 and 0.85 . However, within the North and South Atlantic and the Southern Ocean the data are distributed within a cloud, displaying a much weaker relationship. Some of the increased variability in $\left[\mathrm{O}_{2}\right]$ in the Atlantic basins and Southern Ocean is probably related to seawater temperature differences; colder seawater can contain more dissolved oxygen but also mixing of water masses. Furthermore, $\delta^{13} \mathrm{C}$-DIC distributions in the oceans are also affected by temperature-dependent fractionation during airsea gas exchange (Lynch-Stieglitz et al., 1995) and degree of surface water equilibration with the atmosphere (Schmittner et al., 2013) at source waters, biology, and also mixing with other water masses (Gruber et al., 1999). During glacial times bottom water $\delta^{13} \mathrm{C}$ estimates derived from benthic foraminiferal calcite $\delta^{13} \mathrm{C}$ in the deep $(>\sim 2.5 \mathrm{~km}) \mathrm{At}$ lantic became more depleted (Curry and Oppo, 2005; Oliver et al., 2010), but uncertainties related to preformed $\delta^{13} \mathrm{C}$, air-sea fractionation, and terrestrial biomass contributions to deep water $\delta^{13} \mathrm{C}$-DIC precludes the use of bottom water $\delta^{13} \mathrm{C}$-DIC inferred from benthic foraminifera in the past as a reliable bottom water $\left[\mathrm{O}_{2}\right]$ proxy.

Here we apply the refined bottom water to pore water (at the anoxic boundary) $\delta^{13} \mathrm{C}$ gradient as a quantitative bottom water $\left[\mathrm{O}_{2}\right]$ proxy (Hoogakker et al., 2015). This proxy was originally proposed by McCorkle and Emerson (1988), who observed that the carbon isotope gradient between bottom water and pore water at the anoxic boundary $\left(\left[\mathrm{O}_{2}\right]=0\right)$ 

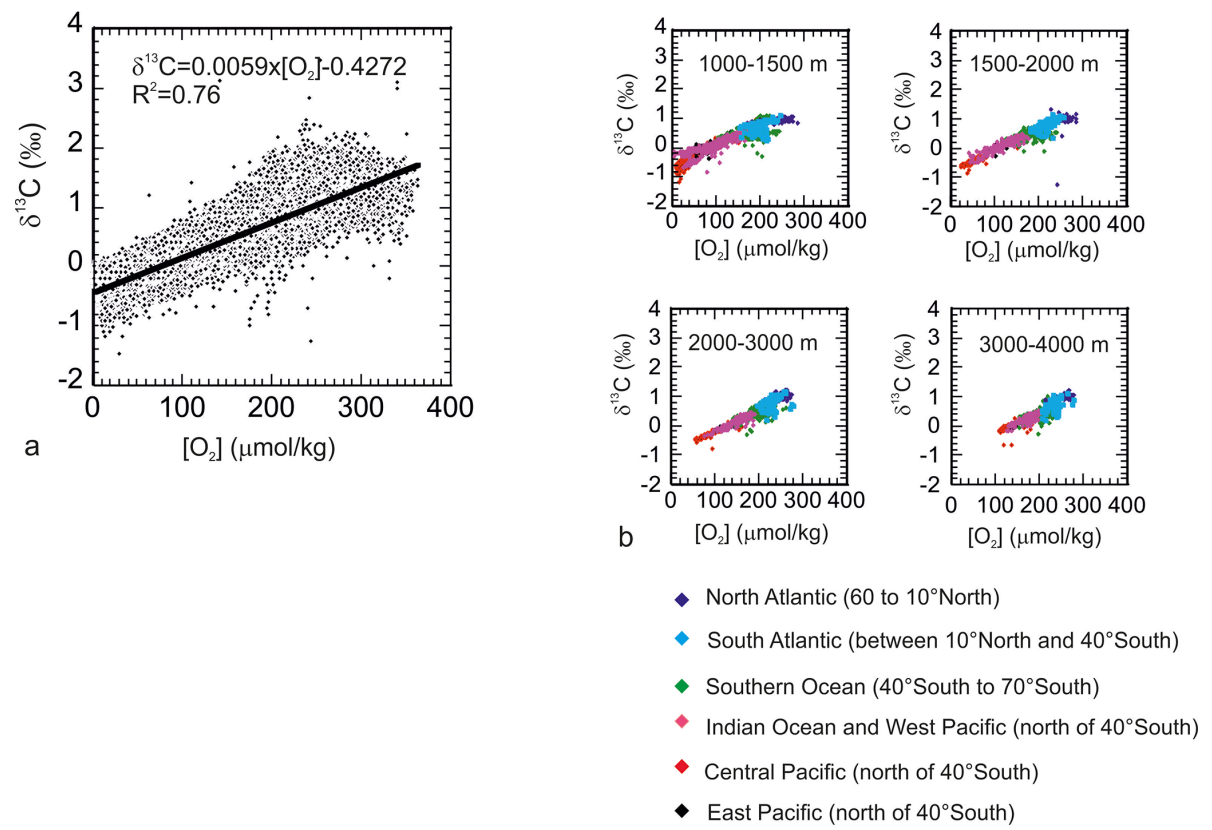

Figure 3. (a) Global relationship between seawater $\left[\mathrm{O}_{2}\right]$ and $\delta^{13} \mathrm{C}$ of DIC. (b) Cross-plots of seawater $\left[\mathrm{O}_{2}\right]$ and $\delta^{13} \mathrm{C}$ for intermediate $(1000-$ 1500 and 1500-2000 m) and deep (2000-3000 and 3000-4000 m) waters. The data used to create this figure can be found in the Supplement and were obtained from http://www.nodc.noaa.gov/OC5/SELECT/dbsearch/dbsearch.html. Only World Ocean Database quality-controlled data with accepted values (e.g. flag 0) are included.

in sediments decreases with decreasing bottom water $\left[\mathrm{O}_{2}\right]$. These changes are attributed to changes in the amount of organic material that can be remineralized; e.g. more organic material can be remineralized under higher bottom water $\left[\mathrm{O}_{2}\right]$, releasing more ${ }^{12} \mathrm{C}$ into the pore waters, increasing the bottom water to anoxic pore water $\delta^{13} \mathrm{C}$ gradient $\left(\Delta \delta^{13} \mathrm{C}_{\text {bw-ab_pw }}\right)$, as supported by pore water $\delta^{13} \mathrm{C}$ and $\left[\mathrm{O}_{2}\right]$ models (McCorkle and Emerson, 1988; Gehlen et al., 1999). Hoogakker et al. (2015) furthermore show that additional observations of $\Delta \delta^{13} \mathrm{C}_{\mathrm{bw}-\mathrm{ab} \_\mathrm{pw}}$, inferred from the difference in $\delta^{13} \mathrm{C}$ between bottom water and foraminifera living at the anoxic boundary (Globobulimina spp.) as well as between bottom water suspension feeding foraminifera (Cibicidoides wuellerstorfi) and anoxic boundary dwelling foraminifera (Globobulimina spp.), all fit the original observations exceptionally well at $\left[\mathrm{O}_{2}\right]$ between 55 and $235 \mu \mathrm{mol} \mathrm{kg}{ }^{-1}$. At higher $\left(>235 \mu \mathrm{mol} \mathrm{kg}{ }^{-1}\right)\left[\mathrm{O}_{2}\right]$, additional light carbon is added to the pore water from other remineralization reactions. These observations confirm that $\delta^{13} \mathrm{C}_{\mathrm{bw}-\mathrm{ab} \_\mathrm{pw}}$ can be approximated by the $\delta^{13} \mathrm{C}$ difference between the test carbonate $\delta^{13} \mathrm{C}$ of benthic foraminiferal species that live in bottom water (e.g. C. wuellerstorfi) and in the sediment at the dysoxic/anoxic boundary (e.g. Globobulimina spp.) at bottom water $\left[\mathrm{O}_{2}\right]$ values of $55-235 \mu \mathrm{mol} \mathrm{kg}{ }^{-1}$, where a $0.39 \%$ o increase in $\Delta \delta^{13} \mathrm{C}_{\mathrm{bw}}$ represents a $50 \mu \mathrm{mol} \mathrm{kg}{ }^{-1}$ increase in bottom water $\left[\mathrm{O}_{2}\right]$ (Hoogakker et al., 2015). Hereafter we refer to this carbon isotope gradient simply as $\Delta \delta^{13} \mathrm{C}$.

\section{Results}

Both records show relatively well-oxygenated water masses for the periods covered, with $\Delta \delta^{13} \mathrm{C}$ values of $1.45 \%$ o and higher (Fig. 4) amounting to bottom water $\left[\mathrm{O}_{2}\right]$ of $144 \mu \mathrm{mol} \mathrm{kg}^{-1}$ and higher (Fig. 5). Typically, seawater is considered hypoxic when $\left[\mathrm{O}_{2}\right]$ values of $60 \mu \mathrm{mol} \mathrm{kg}-1$ or less are recorded, although the median lethal $\left[\mathrm{O}_{2}\right]$ varies between different organisms; temperature and $\mathrm{CO}_{2}$ also influence this threshold (Keeling et al., 2010). At MD95-2042, the LGM (last glacial maximum), MIS 6, and extreme cold events are associated with lower $\left[\mathrm{O}_{2}\right]$ (Hoogakker et al., 2015), with Heinrich event 4 showing the lowest $\Delta \delta^{13} \mathrm{C}$ and thus bottom water $\left[\mathrm{O}_{2}\right]$ (Fig. 4). At the shallower northwest Atlantic ODP Site 1055, MIS 4 and cold events C19, C20, and C21 are associated with a lower $\Delta \delta^{13} \mathrm{C}$ and bottom water $\left[\mathrm{O}_{2}\right]$. From $\sim 62 \mathrm{ka} \mathrm{BP}$ there is gradual increase in $\Delta \delta^{13} \mathrm{C}$, including the latter parts of Heinrich event 6 at ODP Site 1055, although $\Delta \delta^{13} \mathrm{C}$ was lower compared with warm interstadials (Fig. 4).

Hoogakker et al. (2015) calculate that the total error associated with bottom water $\left[\mathrm{O}_{2}\right]$ reconstructions using this method at mid to low latitudes is $17 \mu \mathrm{mol} \mathrm{kg} \mathrm{kg}^{-1}$. This error includes uncertainties associated with variations in the $\delta^{13} \mathrm{C}$ of organic carbon of $\pm 1 \%$ (see Hoogakker et al., 2015 Supplement for details), which seems a reasonable assumption for the low to mid latitude ocean (Goericke and Fry, 1994). Because of decreased $\left[\mathrm{CO}_{2(\mathrm{aq})}\right]$ during full glacial conditions, $\delta^{13} \mathrm{C}_{\text {org }}$ was enriched by $2 \%$ (Rau et al., 1991) causing an 


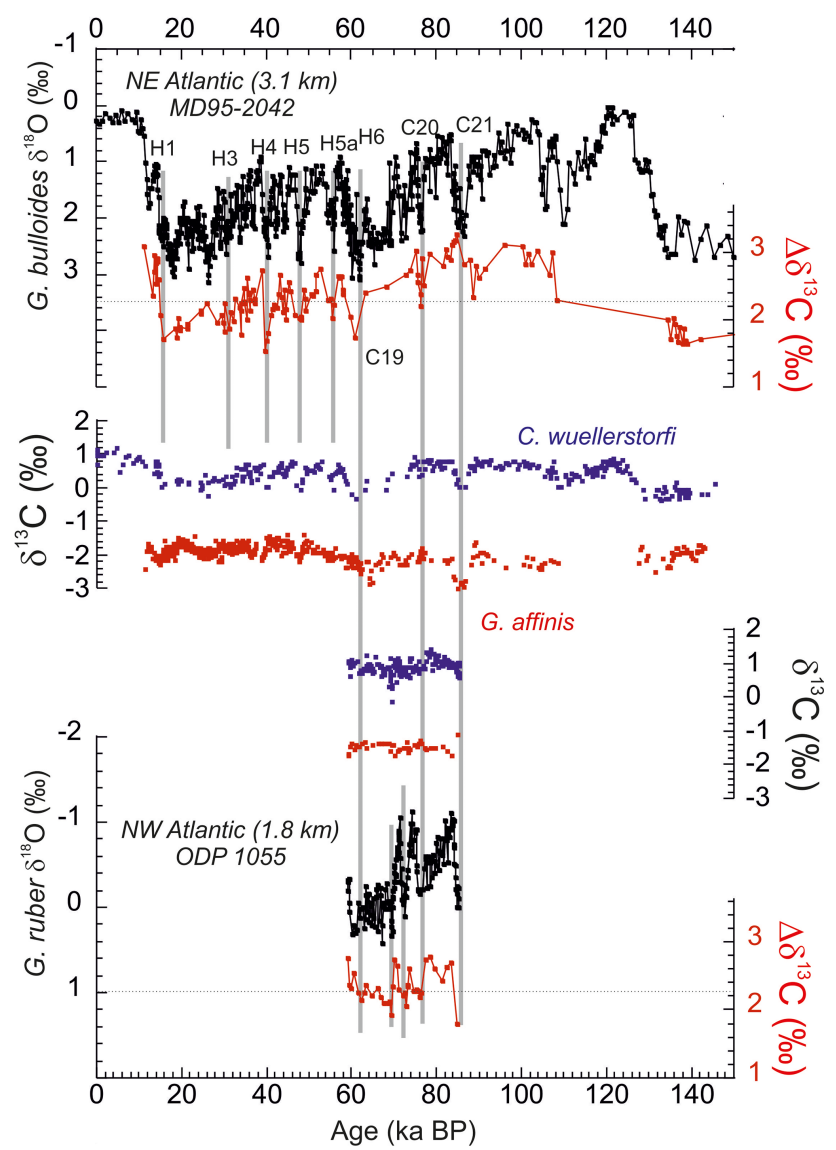

Figure 4. Benthic foraminifera $\Delta \delta^{13} \mathrm{C}$ at deep site MD95-2042 and intermediate ODP Site 1055 and their planktonic foraminifera oxygen isotopes. Original benthic foraminifera $\delta^{13} \mathrm{C}$ records (MD952042 from Shackleton et al., 2000) of epifaunal C. wuellerstorfi (red circles) and deep infaunal $G$. affinis (blue circles) are also shown intercalated between the $\Delta \delta^{13} \mathrm{C}$ records. Several Heinrich events and cold events are shown.

initial overestimation of glacial bottom water $\left[\mathrm{O}_{2}\right]$ and correction of $10 \mu \mathrm{mol} \mathrm{kg}^{-1}$ (Hoogakker et al., 2015). The study of Rau et al. (1991) is of too low resolution to decipher any possible millennial-scale oscillations in $\delta^{13} \mathrm{C}_{\text {org }}$; however, generally $\delta^{13} \mathrm{C}_{\text {org }}$ appears lighter prior to the LGM. It is also important to note that within the North Atlantic Heinrich belt, organic carbon $\delta^{13} \mathrm{C}$ values are depleted during glacial times compared to the Holocene, with the lightest values (up to $-28 \%$ ) during Heinrich events 4, 2, and 1 (Huon et al., 2002; Schouten et al., 2007). Both Huon et al. (2002) and Schouten et al. (2007) attribute these depletions in organic $\delta^{13} \mathrm{C}$ to increased input of terrestrial organic material from either ice-rafted debris or wind-blown sources. It is therefore possible that estimates of $\left[\mathrm{O}_{2}\right]$ during Heinrich events and cold events $\mathrm{C} 20$ and $\mathrm{C} 21$ are overestimated. However, as terrestrial plant remains are generally much older in age (Schouten et al., 2007), it is possible that they are largely refractory (insoluble and non-hydrolyzable) and may not have

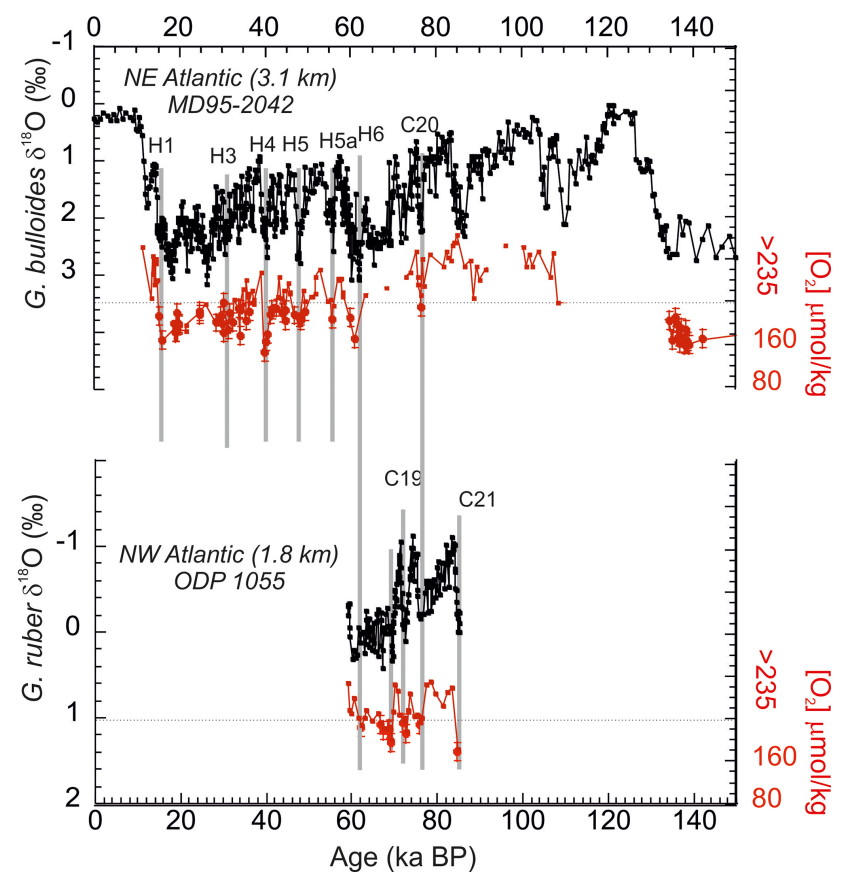

Figure 5. Reconstructed bottom water $\left[\mathrm{O}_{2}\right]$ at deep site MD952042 and intermediate ODP Site 1055 shown with their planktonic foraminifera oxygen isotope records (Shackleton et al., 2000; Thornalley et al., 2013). Heinrich events 1, 3, 4, 5, 5a, and 6 and cold events 19, 20, and 21 are shown.

degraded substantially. Because of this unknown we consider estimates of bottom water $\left[\mathrm{O}_{2}\right]$ during these Heinrich events and cold events $\mathrm{C} 20$ and $\mathrm{C} 21$ as maximum estimates (Fig. 5).

\section{Discussion}

Millennial-scale climate oscillations are a common feature of the last glacial as well as the transition from the previous interglacial (Eemian) to glacial in the North Atlantic (Fig. 2). Within the North Atlantic IRD belt, ice rafting becomes a common feature during millennial-scale cooling events when sea level falls below $-45 \mathrm{~m}$ (Chapman and Shackleton, 2002). Decreased benthic foraminiferal $\delta^{13} \mathrm{C}$ from deep (below $2.5 \mathrm{~km}$ ) sites in the North Atlantic provide evidence for widespread changes in bottom water carbonate chemistry during these events (Shackleton et al., 2000; Sarnthein et al., 2000; Chapman and Shackleton, 2002; Thornalley et al., 2013). Reconstruction of $\left[\mathrm{CO}_{3}^{2-}\right]$ support the inferred changes in deep bottom water carbonate chemistry (Yu et al., 2008). High-resolution intermediate depth North Atlantic records from the northeast Atlantic also generally show lower benthic $\delta^{13} \mathrm{C}$ during Heinrich events (Sarnthein et al., 2000; Chapman and Shackleton, 2002; Rasmussen et al., 2003; Peck et al., 2006; Dickson et al., 2008; Thornalley et al., 2010) whereas ODP Site 1055 from the northwest Atlantic, featured here, shows hardly any change (Evans and 
Table 1. Lowest bottom water $\left[\mathrm{O}_{2}\right]$ associated with Heinrich and extreme cool events and the difference with modern time at intermediate North Atlantic ODP Site $1055\left(254 \mu \mathrm{mol} \mathrm{kg}{ }^{-1}\right.$ today $)$ and deep North Atlantic site MD95-2042 $\left(245 \mu \mathrm{mol} \mathrm{kg}{ }^{-1}\right.$ today). Note that [O 2 ] at MD95-2042 during cold event C20 (indicated with *) is not significantly different from that at modern time.

\begin{tabular}{lrrrr}
\hline & \multicolumn{3}{c}{ Bottom water $\left[\mathrm{O}_{2}\right]$ in $\mu \mathrm{mol} \mathrm{kg}^{-1}\left( \pm 17 \mu \mathrm{mol} \mathrm{kg}^{-1}\right)$} \\
\cline { 2 - 5 } Event & ODP 1055 & Diff. with modern & MD95-2042 & Diff. with modern \\
\hline C21 & 178 & 76 & & \\
C20 & 230 & 24 & 230 & $15^{*}$ \\
C19 & 213 & 41 & & \\
H6 & 224 & 30 & 170 & 75 \\
H5a & & & 206 & 39 \\
H5 & & & 209 & 35 \\
H4 & & & 144 & 101 \\
H3 & & & 181 & 64 \\
H1 & & & 166 & 79 \\
\hline
\end{tabular}

Hall, 2008; Thornalley et al., 2013). During glacial times, reconstructed $\left[\mathrm{CO}_{3}^{2-}\right]$ at North Atlantic sites above $2.8 \mathrm{~km}$ all show increased concentrations (Yu et al., 2008); to date, no inferences have been made with regards to millennial-scale climate oscillations.

During most of MIS 5, including the transition to glacial conditions, the deep northeast Atlantic was well oxygenated (Fig. 5). Between 126 and 109 ka BP G. affinis was absent, probably because a reduced organic carbon flux and deep or weakly developed anoxic boundary meant its microhabitat conditions were not met, similar to Holocene conditions (Hoogakker et al., 2015). Following this period $\Delta \delta^{13} \mathrm{C}$ is $>2.25 \%$, indicating well-oxygenated (> $235 \mu \mathrm{mol} \mathrm{kg}^{-1}$ ) waters. It is not until after $\sim 76 \mathrm{ka} \mathrm{BP}$, coincident with Atlantic cold event $\mathrm{C} 20$, that $\Delta \delta^{13} \mathrm{C}$ of $<2.25 \%$ ore measured (Fig. 4). Applying the $\Delta \delta^{13} \mathrm{C}:\left[\mathrm{O}_{2}\right]$ calibration equation of Hoogakker et al. (2015), we calculate that during Atlantic cold event $\mathrm{C} 20$ bottom water $\left[\mathrm{O}_{2}\right]$ at the Iberian Margin was $230 \pm 17 \mu \mathrm{mol} \mathrm{kg}^{-1}$ (Fig. 5, Table 1). Note that if we had used the present-day $\delta^{13} \mathrm{C}:\left[\mathrm{O}_{2}\right]$ relationship as defined in Fig. 3, bottom water $\left[\mathrm{O}_{2}\right]$ would be drastically underestimated, with bottom water $\left[\mathrm{O}_{2}\right]$ of $\sim 120 \mu \mathrm{mol} \mathrm{kg}{ }^{-1}$ during event $\mathrm{C} 20$. At the Blake Ridge location (ODP Site 1055), $\Delta \delta^{13} \mathrm{C}$ fell below $2.25 \%$ during North Atlantic cold events C21 and C20, giving bottom water $\left[\mathrm{O}_{2}\right]$ of 179 and $230 \pm 17 \mu \mathrm{mol} \mathrm{kg}{ }^{-1}$ respectively (Table 1). Interestingly, during North Atlantic cold event C20 both the deep northeast Atlantic record and intermediate northwest Atlantic record show the same bottom water $\left[\mathrm{O}_{2}\right]$ (Fig. 5).

Between 76 and $64 \mathrm{ka} \mathrm{BP}$, roughly coincident with MIS 4, the record of MD95-2042 does not resolve millennial-scale oscillations, mainly because $C$. wuellerstorfi was not abundant during this time. In the few instances it did occur $\Delta \delta^{13} \mathrm{C}$ was $>2.25 \%$, suggestive of well-oxygenated conditions. At the intermediate depth ODP Site $1055 \Delta \delta^{13} \mathrm{C}$ follows $G$. ruber $\delta^{18} \mathrm{O}$, where lighter $\delta^{18} \mathrm{O}$ values are associated with $\Delta \delta^{13} \mathrm{C}>2.25 \%$ and heavier $\delta^{18} \mathrm{O}$ values, corresponding to millennial-scale cool events, with $\Delta \delta^{13} \mathrm{C}<2.25 \%$ o. During North Atlantic cold event C19, reconstructed bottom water $\left[\mathrm{O}_{2}\right]$ at ODP Site 1055 was $213 \pm 17 \mu \mathrm{mol} \mathrm{kg}^{-1}$, and the cold period that follows is characterized by bottom water $\left[\mathrm{O}_{2}\right]$ of $194 \pm 17 \mu \mathrm{mol} \mathrm{kg}^{-1}$ (Fig. 5, Table 1).

During the later part of MIS 4 and MIS 3, the deep record of MD95-2042 is characterized by bottom water $\left[\mathrm{O}_{2}\right.$ ] variations that follow Greenland climate trends, with high $\Delta \delta^{13} \mathrm{C}$ $(>2.25 \%$ ) values during interstadials, whereas low bottom water $\left[\mathrm{O}_{2}\right]$ characterize Heinrich events, with $\mathrm{H} 6, \mathrm{H} 4$, and $\mathrm{H} 1$ showing lowest bottom water $\left[\mathrm{O}_{2}\right]$ of 170,144 , and $166 \pm 17 \mu \mathrm{mol} \mathrm{kg}^{-1}$ respectively (Fig. 5). Obviously these values still mean well-oxygenated bottom water masses, but they are lower compared with warm interstadial intervals (> $\left.235 \mu \mathrm{mol} \mathrm{kg}^{-1}\right)$ as well as the LGM $\left(200 \pm 17 \mu \mathrm{mol} \mathrm{kg}{ }^{-1}\right)$. At the intermediate location ODP Site 1055, early H6 shows slightly lower bottom water $\left[\mathrm{O}_{2}\right]$ of $224 \pm 17 \mu \mathrm{mol} \mathrm{kg}^{-1}$ followed by an increase to $>235 \mu \mathrm{mol} \mathrm{kg}^{-1}$ (Fig. 5, Table 1).

\section{Causes for millennial-scale bottom water $\left[\mathrm{O}_{2}\right]$ changes}

The glacial decreased bottom water $\left[\mathrm{O}_{2}\right]$ values at the Iberian Margin to $200 \pm 17 \mu \mathrm{mol} \mathrm{kg}^{-1}$ (LGM) and $180 \pm$ $17 \mu \mathrm{mol} \mathrm{kg}{ }^{-1}$ (MIS 6) (compared with $245 \mu \mathrm{mol} \mathrm{kg}{ }^{-1}$ today) have been largely attributed to ocean circulation changes, with a shift in bottom water mass from NADW to SSDW (Hoogakker et al., 2015).

Over the transition from MIS 5 to early MIS 4, a mode change has been suggested in the AMOC (Bereiter et al., 2012; Thornalley et al., 2013; Barker and Diz, 2014, Böhm et al., 2015). Bereiter et al. (2012) suggest that during MIS 5 AMOC was strong, characterized by southward flow of NADW to the deep South Atlantic. This would imply that NADW and NAIW (North Atlantic Intermediate Water) influenced bottom waters at the deep and intermediate sites respectively. Several studies have shown that most cold events within MIS 5 are associated with decreased benthic foraminifera $\delta^{13} \mathrm{C}$ (Shackleton et al., 2000; Oppo et al., 2001; 
Evans and Hall, 2008; Hodell et al., 2009), which have often been interpreted to reflect AMOC changes. Guihou et al. (2010), using the kinematic overturning circulation proxy ${ }^{231} \mathrm{~Pa} /{ }^{230} \mathrm{Th}$, show that AMOC export from the North Atlantic was reduced during the cold events of MIS 5. However, Guihou et al. (2011) further show that cold events within MIS 5 and MIS 4 could be associated with stronger AMOC export at shallow depths, which agrees with grain size results of Thornalley et al. (2013), suggesting more vigorous near-bottom flow speeds during millennial cold events at the intermediate ODP Site 1055. These results confirm inferences of possible strengthened open ocean convection south of the Greenland-Scotland Ridge driving a strong intermediate depth Atlantic Overturning Circulation cell (Thornalley et al., 2013). It would then be somewhat surprising to find lower bottom water $\left[\mathrm{O}_{2}\right]$ during these events as more vigorous North Atlantic Intermediate Water flow is generally associated with better ventilation, although changes in the mode of water mass formation can alter the extent to which newly formed intermediate/deep waters have equilibrated with the atmosphere.

During the glacial, AMOC was considerably different. Rahmstorf (2002) proposed, based on a benthic foraminifera $\delta^{13} \mathrm{C}$ synthesis of Sarnthein et al. (1994), that a deep North Atlantic overturning cell with active deep and intermediate water formation in the North Atlantic and GreenlandIceland-Norwegian (GIN) seas occurred during warm interstadials, active intermediate convection occurred during stadial events, whereas Heinrich events were associated with a significant reduction in overturning strength. Using ${ }^{231} \mathrm{~Pa} /{ }^{230} \mathrm{Th}$ as a kinematic overturning proxy, McManus et al. (2004) suggest that the meridional overturning circulation was significantly reduced during Heinrich Stadial 1. However, the picture appears more complicated. Bottom flow speed reconstruction from the deep $(3.5 \mathrm{~km})$ northwest Atlantic suggests that flow speed changes at this depth follow an Antarctic temperature signal, showing slowdowns in bottom flow vigour coincident with Antarctic warmings (Hoogakker et al., 2007), which have also been linked with bottom water changes (Gutjahr et al., 2010). Both Hoogakker et al. (2007) and Roberts et al. (2010) suggest that perturbations associated with millennial cool events likely only influenced the shallow overturning cell in the North Atlantic. ${ }^{231} \mathrm{~Pa} /{ }^{230} \mathrm{Th}$ reconstructions covering the intermediate northeast Atlantic over $\mathrm{H} 1$ however do not show evidence for a weakened shallow overturning cell (Gherardi et al., 2009). Since then it has emerged that glacial Antarctic Bottom Waters and glacial Antarctic Intermediate Waters might show a see-saw pattern in the North Atlantic during Heinrich events, where deep waters show an increase in the contribution of high-nutrient, low- $\left[\mathrm{O}_{2}\right]$ glacial Antarctic Bottom Waters, and intermediate waters show a decreased contribution of Antarctic Intermediate Water and increased contribution of possibly wellventilated high- $\left[\mathrm{O}_{2}\right]$ Glacial North Atlantic Intermediate Water (Gutjahr et al., 2008, 2010; Huang et al., 2014; Piotrowski et al., 2005). Whilst changes in bottom water mass may thus have some part to play in the bottom water $\left[\mathrm{O}_{2}\right]$ changes at deep sites during Heinrich events, they cannot however explain lower bottom water $\left[\mathrm{O}_{2}\right]$ at the intermediate depth site.

In terms of biological mechanisms driving North Atlantic seawater $\left[\mathrm{O}_{2}\right]$ changes during Heinrich events, the picture is not clear. Model simulations suggest that export production during Heinrich events was globally reduced (Schmittner et al., 2005; Mariotti et al., 2012; Menviel et al., 2014). Interestingly, while Mariotti et al. (2012) suggest an overall decrease in export production in the North Atlantic, model simulations by Menviel et al. (2014) show increases across large areas in the Atlantic. According to Salguiero et al. (2010) there were no changes in productivity in the northeast Atlantic at MD95-2042. However, for the subtropical northeast Atlantic, McKay et al. (2014) inferred increased primary production in surface waters during $\mathrm{H} 1$, causing low-oxygen conditions in the underlying $(2.5 \mathrm{~km})$ sediments. Furthermore, several studies from deep locations in the Atlantic, including the Blake Outer Ridge, Bermuda Rise, the Tobago Basin and equatorial region have documented conspicuous increases in opal sediments during Heinrich events and extreme cold events of MIS 5 (Hoogakker et al., 2007; Keigwin and Boyle, 2008; Gil et al., 2009; Griffiths et al., 2013; Meckler et al., 2013). This could imply a change in productivity at oligotrophic gyre locations in the North Atlantic with increased contribution from opal producers, possibly at the expense of carbonate (foraminifera, coccolith, pteropod, aragonite) producers (Brzezinski et al., 2002; Griffiths et al., 2013). Recent work by Hoogakker et al. (2013) suggests weaker summer stratification in the northwest Atlantic during H5, which could be associated with a deeper mixed layer potentially enhancing silicate available to surface waters. In combination with an increased dust flux (López-Martinez et al., 2006), iron fertilization could have supported diatom productivity. More importantly, whilst export of diatoms to the deep ocean is not that efficient, accumulation of diatom deposits in sediments during Heinrich events (Lippold et al., 2009; Griffiths et al., 2013) could provide evidence that more organic-rich material was exported to greater water depths during these episodes. Based on this evidence we propose that the lower bottom water $\left[\mathrm{O}_{2}\right]$ values at intermediate ODP Site 1055 during extreme millennial-scale cool events were driven by increased export production. The model simulation of Marriotti et al. (2012) and Menviel et al. (2014) also suggests an increase in South Atlantic export production, in agreement with an earlier proxy study by Anderson et al. (2009). In their study, Anderson et al. (2009) found the highest opal fluxes in the Southern Ocean, which were coincident with bottom $\left[\mathrm{O}_{2}\right]$ minima at MD95-2042 of H6, H4, and H1. This implies that biological mechanisms also played a role in decreasing bottom water $\left[\mathrm{O}_{2}\right]$ at the deep site, either by changing the $\left[\mathrm{O}_{2}\right]$ of SSDW in the Southern Ocean or through increased export across the Atlantic. 
Our reconstructed bottom water $\left[\mathrm{O}_{2}\right]$ changes across Heinrich events and extreme cool events of MIS 5 agree with a modelling study of Schmittner et al. (2007), who show that intermediate and deep waters of the North Atlantic were associated with lower bottom $\left[\mathrm{O}_{2}\right]$ during such events. Although the UVic (University of Victoria) model simulations depict the main features of modern oxygen distributions, the North Atlantic results have higher values than observations, whereas large parts of the South Atlantic and Indian/Pacific oceans have lower $\left[\mathrm{O}_{2}\right]$ values compared with observations (Schmittner et al., 2007). Furthermore, while compared with modern time, the model simulations of Schmittner et al. (2007) predict a decrease in bottom water $\left[\mathrm{O}_{2}\right]$ of $60-$ $90 \mu \mathrm{mol} \mathrm{kg} \mathrm{kg}^{-1}$ at the longitude of the intermediate site 1055 and $90-120 \mu \mathrm{mol} \mathrm{kg}^{-1}$ at the longitude of deep site MD952042 during meltwater events, our reconstructions suggests more modest decreases in the range of $24-76 \mu \mathrm{mol} \mathrm{kg}^{-1}(9-$ $30 \%$ ) for the intermediate site, and $15-101 \mu \mathrm{mol} \mathrm{kg}{ }^{-1}(5-$ $40 \%$ ) at the deep site (Fig. 5). The larger amplitude changes in seawater $\left[\mathrm{O}_{2}\right]$ simulated by Schmittner et al. (2007) may be the result of the prescribed pre-industrial boundary conditions with strong AMOC; had they used glacial boundary conditions with weaker AMOC, the oxygen changes at the deep site might have been smaller. However, it is noted that the model outputs depict a particular (extreme) point in model time, whereas reconstructions from deep sea sediments represent an averaged view where extremes have been smoothed out by bioturbation. Our reconstructions agree with model simulations suggesting an overall decrease in North Atlantic $\left[\mathrm{O}_{2}\right]$ during glacial millennial-scale cold events.

\section{Conclusions}

Reconstructions of deep (MD95-2042) and intermediate (ODP Site 1055) water $\left[\mathrm{O}_{2}\right]$ in the North Atlantic during the last glacial portray decreases in bottom water $\left[\mathrm{O}_{2}\right]$ during extreme millennial-scale cool events associated with ice rafting and meltwater release ( $\mathrm{H}$ and $\mathrm{C}$ events). Whilst our reconstructions support previous model simulations suggesting lower seawater $\left[\mathrm{O}_{2}\right]$ during North Atlantic glacial cold events below $\sim 1 \mathrm{~km}$ (Schmittner et al., 2007), our reconstructions are much less dramatic. Numerous observations suggest an increased contribution of SSDW (below $\sim 2 \mathrm{~km}$ ) in the North Atlantic during extreme millennial cool events (H1-H6 and C19-C25), so an increase in high-nutrient, low-[O $\left.\mathrm{O}_{2}\right] \mathrm{SSDW}$ can explain at least part of the reconstructed bottom water $\left[\mathrm{O}_{2}\right]$ change at the deep site. For North Atlantic Intermediate Water, however, there is now evidence suggesting that this overturning cell might have been stronger during millennial cool events. If so, we infer that increased export of organic material from the surface ocean, as observed at numerous locations across the North Atlantic, was responsible for decreased $\left[\mathrm{O}_{2}\right]$ at the intermediate ODP Site 1055. By extrapolation, such mechanisms would have played a part in the deep Atlantic $\left[\mathrm{O}_{2}\right]$ decrease during such events.

\section{The Supplement related to this article is available online at doi:10.5194/bg-13-211-2016-supplement.}

Acknowledgements. Comments from A. Schmittner and an anonymous reviewer improved the quality of our paper. This work is supported by UK Natural Environment Research Council (NERC) grants NE/I020563/1 (to B. A. A. Hoogakker), and NE/J008133/1 and NE/L006405/1 (to S. Barker). This research used samples and/or data provided by the Ocean Drilling Program (ODP). ODP is sponsored by the US National Science Foundation and participating countries (Natural Environment Research Council in the UK) under management of the Joint Oceanographic Institutions (JOI).

Edited by: L. Stramma

\section{References}

Anderson, R. S., Ali, S., Bradtmiller, L. I., Nielsen, S. H. H., Fleisher, M. Q., Anderson, B. E., Burckle, L. H.: Wind-driven upwelling in the Southern Ocean and the deglacial rise in atmospheric $\mathrm{CO}_{2}$, Science, 323, 1443-1448, 2009.

Barker, S. and Diz, P.: Timing of the descent into the last Ice Age determined by bipolar seesaw, Paleoceanography, 29, 489-507, 2014.

Barker, S., Knorr, G., Edwards, R. L., Parrenin, F., Putnam, A. E., Skinner, L. C., Wolff, E., and Ziegler, M.: 800,000 years of abrupt climate variability, Science, 334, 347-351, 2011.

Bassinot, F. C. and Labeyrie, L. D.: Shipboard Scientific Party: IMAGES MD101 Brest-Marseille 29/05/95-11/07/95 - A coring cruise of the R/V Marion Dufresne in the North Atlantic Ocean and Norwegian Sea, Les rapports de campagnes à la mer, Institut Français pour la Recherche et la Technologie Polaires, Technopole de Brest-lroise, BP75-29280 Plouzane, Francee de Brest-lroise, BP 75, 29280 Plouzane, France, 96, 218 pp., 1996.

Bereiter, B., Lüthia, D., Siegrista, M., Schüpbacha, S., Stocker, T. F., and Fischer, $\mathrm{H}$.: Mode change of millennial $\mathrm{CO}_{2}$ variability during the last glacial cycle associated with a bipolar marine carbon seesaw, P. Natl. Acad. Sci. USA, 109, 9755-9760, 2012.

Bond, G. C. and Lotti, R.: Iceberg discharges into the North Atlantic on millennial time scales during the last glaciation, Science, 17, 1005-1010, 1995.

Bopp, L., Le Quéré, C., Heimann, M., Manning, A. C., and Monfray, P.: Climate-induced oxygen fluxes: implications for the contemporary carbon budget, Global Biogeochem. Cy., 16, 1022, doi:10.1029/2001GB001445, 2002.

Böhm, E., Lippold, J., Gutjahr, M., Frank, M., Blaser, P., Antz, B., Fohlmeister, J., Frank, N., Andersen, M. B., and Deininger, M.: Strong and deep Atlantic meridional overturning circulation during the last glacial cycle, Nature, 517, 73-76, 2015. 
Brzezinski, M. A., Pride, C. J., Franck, V. M., Sigman, D. M., Sarmiento, J. L., Matsumoto, K., Gruber, N., Rau, G. H., and Coale, K. H.: A switch from $\mathrm{Si}(\mathrm{OH})_{4}$ to $\mathrm{NO}^{3-}$ depletion in the glacial Southern Ocean, Geophys. Res. Lett., 29, 1564, doi:10.1029/2001GL014349, 2002.

Chapman, M. R. and Shackleton, N. J.: Global ice-volume fluctuations, North Atlantic ice-rafting events, and deep-ocean circulation changes between 130 and $70 \mathrm{ka}$, Geology, 27, 795-798, 2002.

Curry, W. B. and Oppo, D. W.: Glacial water mass geometry and the distribution of $\delta^{13} \mathrm{C}$ of $\sum \mathrm{CO}_{2}$ in the western Atlantic Ocean, Paleoceanography, 20, PA2017, doi:10.1029/2004PA001021, 2005.

Dickson, A. J., Austin, W. E. N., Hall, I. R., Maslin, M. A., and Kucera, M.: Centennial-scale evolution of DansgaardOeschger events in the northeast Atlantic Ocean between 39.5 and $56.5 \mathrm{kaBP}$, Paleoceanography, 23, PA3206, doi:10.1029/2008PA001595, 2008.

Evans, H. K. and Hall, I. R.: Deepwater circulation on Blake Outer Ridge (western North Atlantic) during the holocene, younger dryas, and last glacial maximum, Geochem. Geophy. Geosy., 9, Q03023, doi:10.1029/2007gc001771, 2008.

Gehlen, M., Mucci, A., and Boudreau, B.: Modelling the distribution of stable carbon isotopes in porewaters of deep-sea sediments, Geochim. Cosmochim. Ac., 63, 2763-2773, 1999.

Gherardi, J.-M., Labeyrie, L., Nave, S., Francois, R., McManus, J. F., and Cortijo, E.: Glacial-interglacial circulation changes inferred from $231 \mathrm{~Pa} / 230 \mathrm{Th}$ sedimentary record in the North Atlantic region, Paleoceanography, 24, PA2204, doi:10.1029/2008PA001696, 2009.

Gil, I. M., Keigwin, L. D., and Abrantes, F. G.: Deglacial diatom productivity and surface ocean properties over the Bermuda Rise, northeast Sargasso Sea, Paleoceanography, 24, PA4101, doi:10.1029/2008PA001729, 2009.

Goericke, R. and Fry, B.: Variations of marine plankton $\delta^{13} \mathrm{C}$ with latitude, temperature, and dissolved $\mathrm{CO}_{2}$ in the world ocean, Global Biogeochem. Cy., 8, 85-90, 1994.

Gregory, J. M., Dixon, K. W., Stouffer, R. J., Weaver, A. J., Driesschaert, E., Eby, M., Fichefet, T., Hasumi, H., Hu, A., Junclaus, J. H., Kamenkovich, I. V., Levermann, A., Montoya, M., Murakami, S., Nawrath, S., Oka, A., Solokov, A. P., and Thorpe, R. B.: A model intercomparison of changes in the Atlantic thermohaline circulation in response to increasing atmospheric $\mathrm{CO}_{2}$ concentrations, Geophys. Res. Lett., 32, L12703, doi:10.1029/2005GL023209, 2005.

Griffiths, J. D., Barker, S., Hendry, K. R., Thornalley, D. R., van de Flierdt, T., Hall, I. R., and Anderson, R. F.: Evidence of silicic acic leakage to the tropical Atlantic via Antarctic Intermediate Water during Marine Isotope Stage 4, Paleoceanography, 28, 307-318, 2013.

Gruber, N., Keeling, C. D., Bacastow, R. B., Guenther, P. R., Lueker, T. J., Wahlen, M., Meijer, H. A., Mook, W. G., and Stocker, T. F.: Spatiotemporal patterns of carbon -13 in the global surface oceans and the oceanic Suess effect, Global Biogeochem. Cy., 13, 307-335, 1999.

Guihou, A., Pichat, S., Nave, S., Govin, A., Labeyrie, L., Michel, E., and Waelbroeck, C.: Late slowdown of the Atlantic meriodional overturning circulation during the last glacial inception: new constraints from sedimentary $\left({ }^{231} \mathrm{~Pa} /{ }^{230} \mathrm{Th}\right)$, Earth Planet. Sc. Lett., $289,520-529,2010$.
Guihou, A., Pichat, S., Govin, A., Nave, S., Michel, M., Duplessy, J.-C., Telouk, P., and Labeyrie, L.: Enhanced Atlantic meridional overturning circulation supports the last glacial inception, Quaternary Sci. Rev., 30, 1576-1582, 2011.

Gutjahr, M., Frank, M., Stirling, C. H., Keigwin, L. D., and Halliday, A. N.: Tracing the Nd isotope evolution of North Atlantic deep and intermediate waters in the western North Atlantic since the last glacial maximum from Blake Ridge sediments, Earth Planet. Sc. Lett., 266, 61-77, 2008.

Gutjahr, M., Hoogakker, B. A. A., Frank, M., and McCave, I. N.: Changes in North Atlantic deep water strength and bottom water masses during marine isotope stage 3 (45-55 ka BP), Quaternary Sci. Rev., 29, 2451-2461, 2010.

Heinrich, H.: Origin and consequences of cyclic ice rafting in the northeast Atlantic Ocean during the past 130,000 years, Quaternary Res., 29, 142-152, 1988.

Hodell, D. A., Minth, E. K., Curtis, J. H., McCave, I. N., Hall, I. R., Channell, J. E. T., and Xuan, C.: Surface and deep-water hydrography on gardar drift (Iceland Basin) during the last interglacial period, Earth Planet. Sc. Lett., 288, 10-19, 2009.

Hoogakker, B. A. A., McCave, I. N., and Vautravers, M. J.: Antarctic link to deep flow speed variation during marine isotope stage 3 in the western North Atlantic, Earth Planet. Sc. Lett., 257, 463473, 2007.

Hoogakker, B. A. A., Downy, F., Andersson, M. A., Chapman, M. R., Elderfield, H., McCave, I. N., Lenton, T. M., and Grützner, J.: Gulf-Stream - subtropical gyre properties across two Dansgaard-Oeschger cycles, Quaternary Sci. Rev., 81, 105113, 2013.

Hoogakker, B. A. A., Elderfield, H., Schmiedl, G., McCave, I. N., and Rickaby, R. E. M.: Glacial-interglacial changes in bottomwater oxygen concent on the Portuguese margin, Nat. Geosci., 8, 40-43, 2015.

Huang, K.-F., Oppo, D. W., and Curry, W. N.: Decreased influence of Antarctic intermediate water in the tropical Atlantic during North Atlantic cold events, Earth Planet. Sc. Lett., 389, 200-208, 2014.

Huon, S., Grousset, F. E., Burdloff, D., Bardoux, G., and Mariotti, A.: Sources of fine-sized organic matter in North Atlantic Heinrich Layers: $\delta^{13} \mathrm{C}$ and $\delta^{15} \mathrm{~N}$ tracers, Geochim. Cosmochim. Ac., 66, 223-239, 2002.

Jaccard, S. L., Galbraith, E. D., Sigman, D. M., Haug, G. H., Francois, R., and Pedersen, T. F.: Subarctic Pacific evidence for a glacial deepening of the oceanic respired carbon pool, Earth Planet. Sc. Lett., 277, 156-165, 2009.

Jin, X. and Gruber, N.: Offsetting the radiative benefit of ocean iron fertilization by enhancing $\mathrm{N}_{2} \mathrm{O}$ emissions, Geophys. Res. Lett., 30, 2249, doi:10.1029/2003GL018458, 2003.

Johnsen, S. J., Clausen, H. B., Dansgaard, W., Fuhrer, K., Gundestrup, N., Hammer, C. U., Iversen, P., Jouzel, J., Stauffer, B., and Steffensen, J. P.: Irregular glacial interstadials recorded in a new Greenland ice core, Nature, 359, 311-313, 1992.

Keeling, R. F. and Garcia, H.: The change in oceanic $\mathrm{O}_{2}$ inventory associated with recent global warming, P. Natl. Acad. Sci. USA, 99, 7848-7853, 2002.

Keeling, R. F., Körtzinger, A., and Gruber, N.: Ocean deoxygenation in a warming world, Annu. Rev. Mar. Sci., 2, 199-229, 2010. 
Keigwin, L. D. and Boyle, E. A.: Did North Atlantic overturnin halt 17,000 years ago, Paleoceanography, 23, PA1101, doi:10.1029/2007PA001500, 2008.

Key, R. M., Kozyr, A., Sabine, C. L., Lee, K., Wanninkhof, R., Bullister, J. L., Feely, R. A., Millero, F. J., Mordy, C., and Peng, T.-H., A global ocean carbon climatology: results from GLODAP, Global Biogeochem. Cy., 18, GB4031, doi:10.1029/2004GB002247, 2004.

Kroopnick, P. M.: The distribution of ${ }^{13} \mathrm{C}$ of $\sum \mathrm{CO}_{2}$ in the world oceans, Deep-Sea Res., 32, 57-84, 1985.

Lippold, J., Grützner, J., Winter, D., Lahaye, Y., Mangini, A., and Christl, M.: Does sedimentary 231Pa/230Th from the Bermuda Rise monitor past Atlantic Meridional Overturning Circulation?, Geophys. Res. Lett., 36, L12601, doi:10.1029/2009GL038068, 2009.

López-Martinez, C., Grimalt, J. O., Hoogakker, B., Gruetzner, J., Vautravers, M. J., and McCave, I. N.: Abrupt wind regime changes in the North Atlantic Ocean during the past 30,000-60,000 years, Paleoceanography, 21, PA4215, doi:10.1029/2006PA001275, 2006.

Lynch-Stieglitz, J., Stocker, T. F., Broecker, W. S., and Fairbanks, R. G.: The influence of air-sea exchange on the isotopic composition of oceanic carbon: observations and modeling, Glob. Biogeochem. Cycl., 9, 653-665, 1995.

Mariotti, V., Bopp, L., Tagliabue, A., and Kageyama, M., Swingedouw, D.: Marine productivity response to Heinrich events: a model-data comparison, Clim. Past, 8, doi:10.5194/cp-8-15812012, 2012.

Matear, R. J. and Hirst, A. C.: Long-term changes in dissolved oxygen concentrations in the ocean caused by protracted global warming, Global Biogeochem. Cy., 17, 1125, doi:10.1029/2002GB001997, 2003.

Matear, R. J., Hirst, A. C., and McNeil, B. I.: Changes in dissolved oxygen in the Southern Ocean with climate Change, Geochem. Geophy. Geosy., 1, GC000086, doi:10.1029/2000GC000086, 2000.

McCorkle, D. C. and Emerson, S. R.: The relationship between pore water carbon isotope composition and bottom water oxygen concentration, Geochim. Cosmochim. Ac., 52, 1169-1178, 1988.

McKay, C. L., Filipsson, H. L., Romero, O., Stuut, J.-B. W., and Donner, B.: Pelagic-benthic coupling within an upwelling system of the subtropical northeast Atlantic over the last $35 \mathrm{kaBP}$, Quaternary Sci. Rev., 106, 299-315, 2014.

McManus, J. F., Francois, R., Gherardi, J. M., Keigwin, L. D., and Brown-Leger, S.: Collapse and rapid resumption of Atlantic meridional circulation linked to deglacial climate change, Nature, 428, 834-837, 2004.

Meckler, A. N., Sigman, D. M., Gibson, K. A., François, R., , Martínez-Garcí, A., Jaccard, S. L., Röhl, U., Peterson, L. C., Tiedemann, R., G. H. and Haug, G. H.: Deglacial pulses of deepocean silicate into the subtropical North Atlantic Ocean, Nature, 495, 495-499, 2013.

Menviel, L., England, M. H., Meissner, K. J., Mouchet, A., and Yu, J.: Atlantic-Pacific seesaw and its rol in outgassing $\mathrm{CO}_{2}$ during Heinrich events, Paleoceanography 29, 58-70, 2014.

NGRIP members: High-resolution record of Northern Hemisphere climate extending into the 15 last interglacial period, Nature, 431, 147-151, doi:10.1038/nature02805, 2004.
Nameroff, T. J., Balistrieri, L. S., and Murray, J. W.: Suboxic trace metal geochemistry in the eastern tropical North Pacific, Geochim. Cosmochim. Ac., 66, 1139-1158, 2002.

Oliver, K. I. C., Hoogakker, B. A. A., Crowhurst, S., Henderson, G. M., Rickaby, R. E. M., Edwards, N. R., and Elderfield, H.: A synthesis of marine sediment core $\delta^{13} \mathrm{C}$ data over the last 150 000 years, Clim. Past, 6, 645-673, doi:10.5194/cp-6-645-2010, 2010.

Oppo, D. W., Keigwin, L. D., McManus, J. F., and Cullen, J. L.: Persistent suborbital climate variability in marine isotope stage 5 and termination II, Paleoceanography, 16, 280-292, 2001.

Pailler, D., Bard, E., Rostek, F., Zheng, Y., Mortlock, R., and van Geen, A.: Burial of redox-sensitive metals and organic matter in the equatorial Indian Ocean linked to precession, Geochim. Cosmochim. Ac., 66, 849-865, 2002.

Peck, V. L., Hall, I. R., Zahn, R., Elderfield, H., Grousset, F., Hemming, S. R., and Scourse, J. D.: High resolution evidence for linkages between NW European ice sheet instability and Atlantic Meridional overturning circulation, Earth Planet. Sc. Lett., 243, 476-488, 2006.

Piotrowski, A. M., Goldstein, S. L., Hemming, S. R., and Fairbanks, R. G.: Temporal relationships of carbon cycling and ocean circulation at glacial boundaries, Science, 307, 1933-1938, 2005.

Plattner, G. K., Joos, F., Stocker, T. F., and Marchal, O.: Feedback mechanisms and sensitivities of ocean carbon uptake under global warming, Tellus B, 53, 564-92, 2001.

Rahmstorf, S.: Ocean circulation and climate during the past 120,000 years, Nature, 419, 207-214, 2002.

Rasmussen, T. L., Oppo, D. W., Thomsen, E., Lehman, S. J.: Deep sea records from the southeast Labrador Sea: ocean circulation changes and ice-rafting events during the last 160,000 years, Paleoceanography, 18, 1018, doi:10.1029/2001PA000736, 2003.

Rau, G. H., Froelich, P. N., Takahashi, T., and Des Marais, D. J.: Does sedimentary organic $\delta^{13} \mathrm{C}$ record variations in Quaternary ocean $\left[\mathrm{CO}_{2}(\mathrm{aq})\right]$ ?, Paleoceanography, 6, 335-347, 1991.

Roberts, N. L., Piotrowski, A. M., McManus, J. M., and Keigwin, L. D.: Synchronous deglacial overturning and water mass source changes, Science, 327, 75-78, 2010.

Salguiero, E., Voelker, A. H. L., de Abreu, L., Abrantes, F., Meggers, H., and Wefer, G.: Temperature and productivity changes of the western Iberian margin during the last $150 \mathrm{ky}$, Quaternary Sci. Rev., 29, 680-695, 2010.

Sarmiento, J. L., Hughes, T. M. C., Stouffer, R. J., and Manabe, S.: Simulated response of the ocean carbon cycle to anthropogenic climate warming, Nature, 393, 245-249, 1998.

Sarnthein, M., Winn, K., Jung, S. J. A., Duplessy, J.-C., Labeyrie, L., Erlenkeuser, H., and Ganssen, G.: Changes in east Atlantic deepwater circulation over the last 30,000 years: eight time slice reconstructions, Paleoceanography, 9, 209-267, 1994.

Sarnthein, M., Stattegger, K., Dreger, D., Erlenkeuser, H., Grootes, P., Haupt, B. J., Jung, S., Kiefer, T., Kuhnt, W., Pflaumann, U., Schäfer-Neth, C., Schultz, H., Schultz, M., Seidov, D., Simstich, J., van Kreveld, S., Vogelsang, E., Völker, A., and Weinelt, M.: Fundamental modes and abrupt changes in North Atlantic circulation and climate over the past $60 \mathrm{ky}$ - concepts, reconstruction and numerical modeling, in: From The Northern North Atlantic: A Changing Environment, edited by: Schäfer, P., Ritzrau, W., Schlüter, M., and Thiede, J., Springer, Berlin, 365410, 2000. 
Schmittner, A.: Decline of the marine ecosystem caused by a reduction in the Atlantic overturning circulation, Nature, 434, 628633, 2005.

Schmittner, A. and Lund, D. C.: Early deglacial Atlantic overturning decline and its role in atmospheric $\mathrm{CO}_{2}$ rise inferred from carbon isotopes $\left(\delta^{13} \mathrm{C}\right)$, Clim. Past, 11, 135-152, doi:10.5194/cp11-135-2015, 2015.

Schmittner, A., Galbraith, E. D., Hostetler, S. W., Pedersen, T. F., and Zhang, R.: Large fluctuations of dissolved oxygen in the Indian and Pacific oceans during Dansgaard-Oeschger oscillations caused by variations of North Atlantic deep water subduction, Paleoceanography, 22, PA3207, doi:10.1029/2006PA001384, 2007.

Schmittner, A., Oschlies, A., Matthews, H. D., and Galbraith, E. D.: Future changes in climate, ocean circulation, ecosystems, and biogeochemical cycling simulated for a business-as-usual $\mathrm{CO}_{2}$ emission scenario until year $4000 \mathrm{AD}$, Global Biogeochem. Cy., 22, GB1013, doi:10.1029/2007GB002953, 2008.

Schmittner, A., Gruber, N., Mix, A. C., Key, R. M., Tagliabue, A., and Westberry, T. K.: Biology and air-sea gas exchange controls on the distribution of carbon isotope ratios $\left(\delta^{13} \mathrm{C}\right)$ in the ocean, Biogeosciences, 10, 5793-5816, doi:10.5194/bg-10-5793-2013, 2013.

Schouten, S., Ossebaar, J., Brummer, G. J., Elderfield, H., and Sinninghe Damsté, J. S.: Transport of terrestrial organic matter to the deep North Atlantic Ocean by ice rafting, Org. Geochem., 38, 1161-1168, 2007.

Shackleton, N. J., Hall, M. A., and Vincent, E.: Phase relationships between millennial-scale events 64,000-24,000 years ago, Paleoceanography, 15, 565-569, 2000.

Shackleton, N. J., Fairbanks, R. G., Chiu, T.-C., and Parrenin, F.: Absolute calibration of the Greenland time scale: implications for Antarctic time scales and for $\Delta^{14} \mathrm{C}$, Quaternary Sci. Rev., 23, 1513-1522, 2004.

Shaffer, G., Olsen, S. M., and Pedersen, J. O. P.: Long-term ocean oxygen depletion in response to carbon dioxide emissions from fossil fuels, Nat. Geosci., 2, 105-109, 2009.

Skinner, L. C. and Shackleton, N. J.: Rapid transient changes in northeast Atlantic deep water ventilation age across termination I, Paleoceanography, 19, PA2005, doi:10.1029/2003PA000983, 2004.

Skinner, L. C., Fallon, S., Waelbroeck, C., Michel, E., and Barker, S.: Ventilation of the deep Southern Ocean and deglacial $\mathrm{CO}_{2}$ rise, Science, 328, 1147-1151, 2010.

Stahr, F. R. and Sanford, T. B.: Transport and bottom boundary layer observations of the North Atlantic Deep Western Boundary current at the Blake Outer Ridge, Deep-Sea Res. Pt II, 46, 205-243, 1999.

Stocker, T. F. and Johnson, S. J.: A minimum thermodynamic model for the bipolar seesaw, Paleoceanography, 18, 1087, doi:10.1029/2003PA000920, 2003.

Stramma, L., Schmidtko, S., Levin, L. A., and Johnson, G. C.: Ocean oxygen minima expansions and their biological impacts, Deep-Sea Res. Pt. I, 57, 587-595, 2010.

Thornalley, D. J. R., Elderfield, H., and McCave, I. N.: Intermediate and deep water paleoceanography of the northern North Atlantic over the past 21,000 years, Paleoceanography, 25, PA1211, doi:10.1029/2009PA001833, 2010.
Thornalley, D. J. R., Barker, S., Becker, J., Hall, I. R., and Knorr, G.: Abrupt changes in deep Atlantic circulation during the transition to full glacial conditions, Paleoceanography, 28, 253-262, doi:10.1002/palo.20025, 2013.

Yu, J., Elderfield, H., and Piotrowski, A. M.: Seawater carbonate ion- $\delta^{13} \mathrm{C}$ systematics and application to glacial-interglacial North Atlantic ocean circulation, Earth Planet. Sc. Lett., 271, 209-220, 2008. 